\title{
Phytochemical and Pharmacological Evaluation of Jatropha curcas Seed Extract
}

\author{
A. Narendra Babu*, SK. Ayesha, S. Nirosha, V. L. Mounika, J.Naga Lakshmi \\ Department of Pharmacology, Chalapathi Institute of Pharmaceutical Sciences, Chalapathi nagar, Lam, Guntur, Andhra Pradesh, India. \\ *Corresponding author's E-mail: narendraankem@rediffmail.com
}

Received: 06-01-2021; Revised: 21-02-2021; Accepted: 25-02-2021; Published on: 20-03-2021.

\section{ABSTRACT}

Aggression can emit to vulnerability to a frightening situation. Aggression is caused by a heterogeneous mixture of social, psychologic and biological factors. Aggression is prominently seen when a disturbance occurs in the fine balance of neurotransmitters such as 5 hydroxytryptamine, gamma-aminobutyric acid, dopamine and their receptor subtypes. The present study investigated the ability of aqueous extract of Jatropha curcas seeds (AEJC) evade aggression. Foot shock induced aggression test was utilized as model for screening of anti-aggressive activity. Extract was given orally at a dose level $(100$ and $250 \mathrm{mg} / \mathrm{kg}$ ) once daily for three days, while Diazepam $(2.5 \mathrm{mg} / \mathrm{kg})$, was administered as reference standard. Control group animals were given an equal volume of vehicle (10\%, v/v, TWEEN 80 suspension). As a result, Jatropha curcas Linn seed extract (AEJC) has a gentle anti-aggressive activity qualitatively comparable to that of diazepam.

Keywords: Aggression, 5-hydroxytryptamine, gamma-aminobutyric acid, Jatropha curcas, Diazepam.

QUICK RESPONSE CODE $\rightarrow$
DOI:
10.47583/ijpsrr.2021.v67i01.014
DOI link: $\underline{\text { http://dx.doi.org/10.47583/ijpsrr.2021.v67i01.014 }}$

\section{INTRODUCTION}

ocial conflict and intra-specific aggression are key aspects of natural animal behaviour and have been shown to be a biologically relevant mean of examining central neurochemical functions. A number of ways have been developed to induce aggression in mice. Administration of anxiolytic agents has been found to be useful in the suppression of aggressive behaviour in animal models ${ }^{1}$.

Aggression is a deliberate series of actions that lead to harm or injury to another organism and thus constituting a major public health concern across the globe. In clinical settings, aggression has been classified into two more specific subtypes, such as proactive and reactive aggression. Proactive aggression is over controlled, planned, predatory and driven by reward contingencies, whereas reactive aggression is generally characterized by an over aroused and impulsive response to a perceived threatening stimulus, with a single goal of reducing or eliminating the perceived threat ${ }^{2}$. Offensive aggression in animals possesses many of the characteristic features of reactive aggression in human beings including impulsive responses and neurochemical abnormalities ${ }^{3}$. The use of animal models of aggression affords the possibility of assessing the effects of drugs on specific types of aggression.
Aggression is caused by a heterogeneous mixture of social, psychologic and biological factors. Involvement of $\gamma$ aminobutyric acid (GABA)-ergic neurotransmission in the neurobiology of aggressive behaviour has often been reported. It has been suggested that agents acting on the $\mathrm{GABA}_{A}$ receptor complex, could be biological modulators of aggression ${ }^{4}$. It has also been reported that small amounts of alcohol, the neuroactive steroid $3 \alpha, 5 \alpha$ tetrahydro progesterone and benzodiazepines may heighten aggression in humans as well as in animals, whereas higher doses reduce aggression ${ }^{5}$.

Despite advances in western system of medicine and medical technology world over, its increasingly being realized that if we have to support the healthcare requirements of our ever-increasing population, we will have resort to economical, yet effective alternatives and there cannot be a better alternative than the herbal drugs which have had a long history of safe usage in different parts of the world, including India. The attention of the world is now being drawn more and more to herbs and herbal medicines as the synthetic drugs seem to have come up against a wall in the treatment of illness which is described as life style diseases ${ }^{6}$.

The seeds of Jatropha curcas have good potentials as a fuel substitution. However, the seeds in general, are toxic to human and animals. Curcin is a toxic protein isolated from the seeds, and also contains a high concentration of phorbol esters ${ }^{7,8}$. The seed is used for the treatment of arthritis, gout and jaundice. ${ }^{9}$ The seed of this plant has also been used traditionally for the treatment of many ailments including burns, convulsions, fever and inflammation ${ }^{10}$. The seed oil can be applied to treat eczema and skin diseases and to sooth rheumatic pain ${ }^{11}$. The oil is also used externally for the treatment of sciatica, dropsy and 
paralysis ${ }^{12}$. The linoleic acid (36\%) content Jatropha curcas kernel oil is the possible interest for skin care ${ }^{13}$. The oil has a strong purgative action and also is widely used for skin diseases and to sooth pain such as pain caused by rheumatism. Also, as reported, the seed oil can be a remedy against syphilis. In South Sudan, the seeds as well as the fruits are used as a contraceptive or as abortifacient ${ }^{14}$.

Keeping in view of wide range beneficial effects of Jatropha curcas Linn seeds, the present study was undertaken to determine the influence of the aqueous extract of Jatropha curcas seeds on the aggressive behavior in mice, using the foot-shock induced aggression method.

\section{MATERIALS AND METHODS}

\section{Plant material}

The plant material consists of dried powdered seeds of Jatropha curcas belonging to the family Euphorbiaceae.

\section{Preparation of plant extract}

Fresh seeds of Jatropha curcas Linn. were collected, shade dried and coarsely powdered. The seed powder was extracted with solvent like water by Soxhlation method, then the extracted solvent was filtered and filtrate was concentrated using a Rota Evaporator. The concentrated plant extract was used for the pharmacological activities.

\section{Drug treatments}

Diazepam was purchased from Sigma-Aldrich, Bangalore and tween 80 was purchased locally. Drug treatments based on our earlier studies, the aqueous extract of Jatropha curcas was administered orally, as a tween 80 suspension in doses of 100 and $250 \mathrm{mg} / \mathrm{kg}$ of body weight, once daily for 3 consecutive days. Experiments were conducted on day $4,1 \mathrm{~h}$ after the last oral treatment. Diazepam ( $2.5 \mathrm{mg} / \mathrm{kg}$, p.o.) was used as the standard antiaggressive agent. Control animals were treated with an equal volume of vehicle $(10 \%, v / v$, tween 80$)$.

\section{Animals}

Male mice, weighing around 25-30g were employed in the present study. They were obtained from animal house of Chalapathi Institute of Pharmaceutical Sciences, Guntur (Reg.No. 1048/PO/Re/S.07/CPCSEA). The experimental protocol was priorly approved by the Institutional Animal Ethics Committee (IAEC) of Chalapathi Institute of Pharmaceutical Sciences, Guntur, Andhra Pradesh. Animals were randomly housed in groups of four in polypropylene cages at an ambient temperature of $25 \pm$ $1^{\circ} \mathrm{C}$ and $45-55 \%$ relative humidity, with a $12 \mathrm{~h}$ light/dark cycle. The animals had free access to standard pellet and water ad libitum.

\section{Experimental methods}

The most widely used rodent model often used to detect potential effects of a therapeutically used anxiolytic drugs on aggression viz.: foot shock-induced aggression was chosen to evaluate the effect of Jatropha Curcas on aggressive behaviour.

Foot shock-induced aggression:

Weight matched Swiss mice were divided into four groups (each group containing 5 pairs).

$>$ Group I (Vehicle control) - Mice were administered Tween $80(1 \mathrm{ml} / \mathrm{Kg})$ orally.

$>$ Group II (AEJC, $100 \mathrm{mg} / \mathrm{Kg}$ ) - Mice were administered Jatropha curcas seed extract (100 mg/Kg) orally.

$>$ Group III AEJC, $\mathbf{2 5 0}$ mg/Kg)- Mice were administered Jatropha curcas seed extract (100 mg/kg) orally.

$>$ Group IV (Diazepam treated group) - Mice were administered Diazepam (2.5 mg/Kg) orally.

The animals were treated with vehicle, AEJC (100 and 250 $\mathrm{mg} / \mathrm{kg}$ ) and diazepam respectively, once daily for 3 consecutive days. On the 4 th day, $1 \mathrm{~h}$ after the last oral treatment, all pairs of mice were subjected to foot shock by placing them in an aggress meter (Techno) for $3 \mathrm{~min}$. During a $3 \mathrm{~min}$ observation period, every $5 \mathrm{sec}$ a $60-\mathrm{Hz}$ current was delivered for $5 \mathrm{sec}$. Each pair of mice was dosed and tested without previous exposure. The total number of fights were recorded for each pair ${ }^{15}$. The fighting behavior consists of VOCALIZATION, LEAPING, REARING and FACING EACH OTHER with some attempt to attack by HITTING, BITING or BOXING.

\section{Statistical analysis}

The results are expressed as mean \pm standard error of means (S.E.M.). The data of neurotoxicity results were statistically analyzed by Two-way analysis of variance (ANOVA) followed by Tukey's multiple range test using graph pad prism version 6.0.

\section{RESULTS AND DISCUSSION}

\section{Physicochemical analysis}

The coarse powder of Jatropha curcas Linn. seeds was subjected to phytochemical screening,

Table 1: Phytoconstituents present in AEJC

\begin{tabular}{|c|c|c|}
\hline S. No & PHYCONSTITUENT & AEJC \\
\hline 1 & Steroids \\
\hline & a) Salkwoski test & --- \\
\hline 2 & b) Liebermann buchard'stest & --- \\
\hline & Carbohydrates & \\
\hline & a) Fehling's test & ++ \\
\hline & b) Molisch's test & ++ \\
\hline 3 & c) Benedict's test & ++ \\
\hline & a) Broteins & \\
\hline b) Millons test & --- \\
\hline c) Ninhydrin test & --- \\
\hline
\end{tabular}




\begin{tabular}{|c|c|c|c|c|c|}
\hline & \multicolumn{2}{|l|}{ Alkaloids } & & b)Lead acetate test & --- \\
\hline & a) Mayer's test & --- & \multirow{3}{*}{8} & \multicolumn{2}{|l|}{ Flavonoids } \\
\hline & b) Dragendroff's test & --- & & a)Alkaline reagent test & --- \\
\hline & c) Wagner's test & -- & & b) Zinc hydrochloride test & -- \\
\hline & d) Hager's test & --- & \multirow{3}{*}{9} & \multicolumn{2}{|l|}{ Triterpenoids } \\
\hline 4 & \multicolumn{2}{|l|}{ Glycosides } & & a) Salkowski test & ++ \\
\hline \multirow[t]{2}{*}{5} & a) Brontragers test & ++ & & b) Liebermann buchard's test & ++ \\
\hline & b) Modified brontragers test & ++ & 10 & Fixed oil & --- \\
\hline \multirow{2}{*}{6} & \multicolumn{2}{|l|}{ Saponins } & 11 & Volatile oils & ++ \\
\hline & a)Foam test & --- & 12 & Gums \& mucilages & --- \\
\hline \multirow{2}{*}{7} & \multicolumn{2}{|l|}{ Tannins } & \multirow{2}{*}{\multicolumn{3}{|c|}{$\begin{array}{l}\text { ++ indicates Presence } \\
\text {--- indicates Absence }\end{array}$}} \\
\hline & a) Ferric chloride test & --- & & & \\
\hline
\end{tabular}

Table 2: Effects of AEJC and diazepam on aggressive behaviour in the foot shock induced aggression test. Each value *5represents the mean $( \pm$ SEM) for 5 pairs of roats in each group

\begin{tabular}{|l|c|c|c|c|c|}
\hline & \multicolumn{5}{|c|}{ Behavioural response } \\
\hline $\begin{array}{l}\text { Treatment } \\
\text { (Dose) }\end{array}$ & Vocalization (No.) & Leaping (No.) & Rearing (No.) & Facing each other (No.) & $\begin{array}{c}\text { No. of fighting } \\
\text { bouts }\end{array}$ \\
\hline $\begin{array}{l}\text { Vehicle Control } \\
\text { Diazepam }\end{array}$ & $134.7 \pm 1.71$ & $33.83 \pm 1.42$ & $27.2 \pm 1.22$ & $10.8 \pm 0.60$ & $12.7 \pm 0.80$ \\
\hline$(2.5 \mathrm{mg} / \mathrm{Kg})$ & $139.5 \pm 1.18^{* * * *}$ & $25.5 \pm 1.18^{* * * *}$ & $18.3 \pm 0.88^{* * * *}$ & $5.7 \pm 0.42^{* * * *}$ & $6.3 \pm 0.84^{* * * *}$ \\
\hline $\begin{array}{l}\mathrm{AEJC} \\
(100 \mathrm{mg} / \mathrm{kg})\end{array}$ & $135.8 \pm 1.25$ & $32.5 \pm 1.20$ & $25.3 \pm 1.38$ & $9.8 \pm 0.48$ & $11.2 \pm 0.87$ \\
\hline $\begin{array}{l}\mathrm{AEJC} \\
(250 \mathrm{mg} / \mathrm{kg})\end{array}$ & $136.5 \pm 1.23$ & $29.2 \pm 0.79 * * *$ & $23.0 \pm 1.13^{* * *}$ & $8.6 \pm 0.75$ & $9.7 \pm 0.72^{*}$ \\
\hline
\end{tabular}

$*=\mathrm{p}<0.05, * * *=\mathrm{p}<0.001, * * * *=\mathrm{p}<0.0001$ compared to vehicle

In preliminary phytochemical studies the aqueous extract of Jatropha curcas (AEJC) showed presence of carbohydrates, proteins, alkaloids, glycosides, tannins, flavonoids, triterpenoids, volatile oils (Table No:1).

The administration of AEJC (250 mg/Kg) showed a reduction in leaping, rearing $(p<0.001)$ behaviour and dose dependent decrease in the number of fights in foot shockinduced aggression, as compared with vehicle. Further AEJC $(250 \mathrm{mg} / \mathrm{Kg})$ exhibited significant $(P<0.05)$ decrease in the number of fights, but $100 \mathrm{mg} / \mathrm{kg}$ did not produce any significant effect. The diazepam $(2.5 \mathrm{mg} / \mathrm{Kg})$ treated group showed a statistically significant $(p<0.0001)$ decrease in behavioural response viz. vocalization, leaping, rearing, and the number of fights. [Table No.2].

Therefore, anti aggresive activity of AEJC evidenced by the results adds a new potential use in the wide spectrum of herbal drugs for the treatment of neurological disorders.

\section{CONCLUSION}

From the preliminary phytochemical analysis, it was evidenced that Jatrapha curcas seed extract contains the vital constituents like triterpinoids, volatile oils, proteins and glycosides. The experimental results we can conclude that aqueous extract of Jatrapha curcas seeds has a significant anti-aggressive activity. But in contrast to standard drug (diazepam), it was found to be gentle.

\section{REFERENCES}

1. Bansinath $\mathrm{M}$, Ramabadran K. Bioscreening technique for antipsychotic activity. Chapter 3. In: Drug Bioscreening. Drug evaluation techniques in pharmacology. Emmanuel B. Thompson, VCH Publisher, Inc. 1990; p. 40-45.

2. Weinshenker NJ, Siegel A. Bimodal classification of aggression: affective defense and predatory attack. Agg. Viol. Behav. 2002; 7: 237-50.

3. Blanchard RJ, Blanchard DC. What can animal aggression research tell us about human aggression. Horm. and Behav. 2003; 44: 171-7.

4. Watanabe H. Psychotropic effects of Si-Wu-Tang, a SinoJapanese traditional prescription: Effects on stressinduced behavioural changes and on spatial cognitive deficit in experimental animals. J. Braz. Assoc. Adv. Sci. 1996; 48(4): 226-30.

5. Spalletta G, Romeo E, Bonaviri G, Bernardi G, Caltagirone C, Di Michele F. Preliminary evidence for an association between aggressive and hostile behaviour and $3 \alpha, 5 \alpha$ - tetra hydro progesterone plasma levels in schizophrenia. J. Psych. Neurosci. 2005; 30(1): 49-52. 
6. Handa SS. Road to therapeutics: drugs from plants. Speakers at a glance. New Delhi: International Conference on Translational Pharmacology. 2008; 1-8.

7. Adolf W, Opferkuch HJ, Hecker E. Irritant phorbol derivatives from four Jatropha species. Phytochem. 1984; 23: $129-132$.

8. Makkar HPS, Becker K, Sporer F, Wink M. Studies on nutritive potential and toxic constituents of different provenances of Jatropha curcas. J. Agric. Food Chem. 1997; 45: 3152-3157.

9. Khafagy SM, Mohamed YA, Abdel SNA, Mahmoud ZF (1977). Phytochemical study of Jatropha curcas. Planta Med. 1977; 31: 274-277.

10. Osoniyi O, Onajobi F. Coagulant and anticoagulant activities in Jatropha curcas. J. Et.pharmacol. 2003; 89: 101105.
11. Heller J. Promoting the Conservation and use of Underutilized and Neglected Crops. Physic Nut. Jatropha curcas L. International Plant Genetic Resources Institute, Rome. 1996. P.1-66.

12. Mujamdar AM, Visar AV. Anti-inflammatory activity of Jatropha curcas roots in mice and rats. J. Eth. Pharmacol. 2004; 90: 11-15.

13. Kumar A, Sharma S. An evaluation of multipurpose oil seed crop for industrial uses (Jatropha curcas L.): A review. Bios Eng., 2008; 97: 201-207.

14. List PH, Horhammer L (1979). Hager's Handbuch der Pharmazeutischen Praxis, Springer, Berlin. (1979).

15. Vogel HG (ed.). Drug Discovery and Evaluation: Pharmacological Assays. $2^{\text {nd }}$ ed., Springer-Verlag, Heidelberg, Germany, 2002; p. 425-430.

\section{Source of Support: None declared.}

Conflict of Interest: None declared.

For any question relates to this article, please reach us at: editor@globalresearchonline.net New manuscripts for publication can be submitted at: submit@globalresearchonline.net and submit_ijpsrr@rediffmail.com 